\title{
Диференціація сортозразків
}

\section{пшениці м'якої озимої за кількістю колосків у колосі}

\author{
Литус М. В.1 \\ Стариченко В. М. ${ }^{2}$, кандидат сільськогосподарських наук \\ 1Черкаська державна сільськогосподарська дослідна станція \\ ННЦ «Інститут землеробства НААН» \\ Україна, 20731, с. Холоднянське, вул. Докучаєва, 13, \\ Смілянський район Черкаської обл. \\ e-mail: iznaan@ukr.net \\ ${ }^{2}$ ННЦ «/нститут землеробства НАAН» \\ Україна, 08162, смт. Чабани, вул. Машинобудівників, 2-Б, \\ Києво-Святошинський район Київської обл. \\ e-mail: stvas@ukr.net
}

Мета. Проаналізувати за кількістю колосків у колосі колекційний матеріал пшениці м'якої озимої для отримання селекційним шляхом генотипів зі спадково обумовленою великою кількістю колосків і високою адаптивністю до абіотичних факторів. Методи. Дослідження проводили у 2010-2012 рр. в польових умовах селекційнонасіннєвої сівозміни Черкаської державної сільськогосподарської дослідної станції. Вивчення і оцінку колекційного матеріалу (87 сортозразків пшениці озимої різного еколого-географічного походження) проводили за методиками BIP та державного сортовипробування сільськогосподарських культур, математичну обробку даних методом дисперсійного аналізу за Б. О. Доспєховим та А. Афіфі, С. Ейзеном з використанням програм Microsoft Excel i Statistica 6.0. Мінливість господарськи цінних ознак колекційних зразків озимої пшениці вивчали за елементами продуктивності колоса (кількість колосків у колосі, довжина колоса, кількість зерен у колосі, маса зерна з колоса, маса 1000 зерен) та врожайністю. Результати. Структурний аналіз показав, що в середньому за три роки (2010-2012) кількість колосків у колосі досліджуваних сортозразків озимої пшениці різного еколого-географічного походження коливалась від 11,7 до 19,7 шт. (середнє значення ознаки - 16,5 шт.), найбільшим цей показник був в українських сортозразків Вільшана (19,0 шт.), Декан (19,7 шт.), Знахідка / KS93 WERCZ (19,3 шт.), німецьких SAMYRAJ (19,0 шт.), DROMOS (19,3 шт.), а також AC MACKINNON із CША (19,0 шт.), MILDA з Латвії (18,0 шт.), SEDA з Литви (18,0 шт.), NS-124-01 із Сербії (18,3 шт.), найменшим - у сортів із США HАTTON (11,7 шт.) та CARLISLE (13,7 шт.), українських Достаток (12,7 шт.), Солоха (14,3 шт.), Крижинка / SR (13,7 шт.) та російського сорту Волжская (14,3 шт.). Кількість колосків у колосі $€$ досить мінливою за роками ознакою. Не відмічено її зв'язку з тривалістю вегетаційного періоду. Найвищий кореляційний зв'язок кількості колосків у колосі з іншими ознаками встановлено для довжини колоса $(r=+0,57)$. Висновки. Сортозразки диференційовано за кількістю колосків у колосі. Встановлено значний кореляційний зв'язок кількості колосків у колосі з довжиною колоса та слабкий достовірний з кількістю зерен у колосі та масою зерна з колоса.

Ключові слова: пшениця озима, селекція, кількість колосків у колосі, продуктивність колоса, еколого-географічне походження, урожайність 
Вступ. Особливості будови суцвіття зернових злаків визначають важливі господарські ознаки цих культур, впливають на продуктивність. Суцвіття пшениці та жита - колос. Вісь колоса складається із члеників, на верхній частині кожного з яких в уступах колосового стрижня розміщено по одному сидячому колоску. Колосок - унікальна структура, що характерна тільки для злаків, являє собою редуковану гілку, на якій розміщені квітки. Двостатеві квітки розміщені на осі колоса і захищені квітковими лусками $[1,2]$.

Аналіз літературних джерел, постановка проблеми. Пшениця м'яка Triticum aestivum L. характеризується різними морфологічними ознаками, які генетично обумовлені кількістю і будовою хромосом у процесі еволюції і природного добору, що забезпечує виключно багатий генетичний ресурс для поліпшення цієї культури. Урожай зерна типового сорту пшениці складається з трьох компонентів: кількості колосів на рослину, зерен у колосі та маси зерна з колоса. Кількість зерен на рослину може бути розподілена на два субкомпоненти: колосків на колос та зернин у колоску. Зростання кожного з цих компонентів прямо впливає на врожай зерна. У типового сорту пшениці на верхівці головного стебла та кожного фертильного підгону утворюється по одному колосу, а підгони, які не продукують колос, є стерильними $[3,4]$.

Кількість колосків у колосі залежить від генетичних чинників та агрометеорологічних умов, у яких росте і розвивається рослина. До негенетичних чинників крім агрометеорологічних умов належать також можливості технології вирощування. За допомогою відповідних агрозаходів можна не тільки збільшити кількість колосків, а й зменшити їх редукцію $[5,6]$.

Мета досліджень - проаналізувати за кількістю колосків у колосі наявну колекцію пшениці м'якої озимої для отримання селекційним шляхом генотипів зі спадково обумовленою великою кількістю колосків і високою адаптивністю до абіотичних факторів.

Матеріал та методика. Дослідження проводили у 2010-2012 рр. в польових умовах селекційно-насіннєвої сівозміни Черкаського інституту агропромислового виробництва (нині Черкаська державна сільськогосподарська дослідна станція ННЦ «Інститут землеробства НААН»). Грунт дослідних ділянок - чорнозем малогумусний реградований середньосуглинковий на карбонатному лесі. Особливістю кліматичних умов зони є нестійке зволоження. Періодично проявляються грунтові та повітряні посухи. Але в більшості років сільськогосподарські культури забезпечують високий урожай і формують високоякісне насіння. 
Вивчення і оцінку колекційного матеріалу пшениці озимої проводили за методиками BIP [7] та державного сортовипробування сільськогосподарських культур [8], математичну обробку даних - методом дисперсійного аналізу за Б. О. Доспєховим [9], А. Афіфі та С. Ейзеном [10] 3 використанням програм Microsoft Excel i Statistica 6.0.

Досліджували мінливість господарськи цінних ознак у 87 сортозразків пшениці озимої різного еколого-географічного походження. Стандарт - сорт Смуглянка. Проводили структурний аналіз колекційних зразків озимої пшениці за елементами продуктивності колоса (кількість колосків у колосі, довжина колоса, кількість зерен у колосі, маса зерна 3 колоса, маса 1000 зерен) та врожайністю.

Обговорення результатів. У середньому за три роки (2010-2012) кількість колосків у колосі коливалась від 11,7 до 19,7 шт., середнє значення ознаки становило 16,5 шт. (рис. 1).

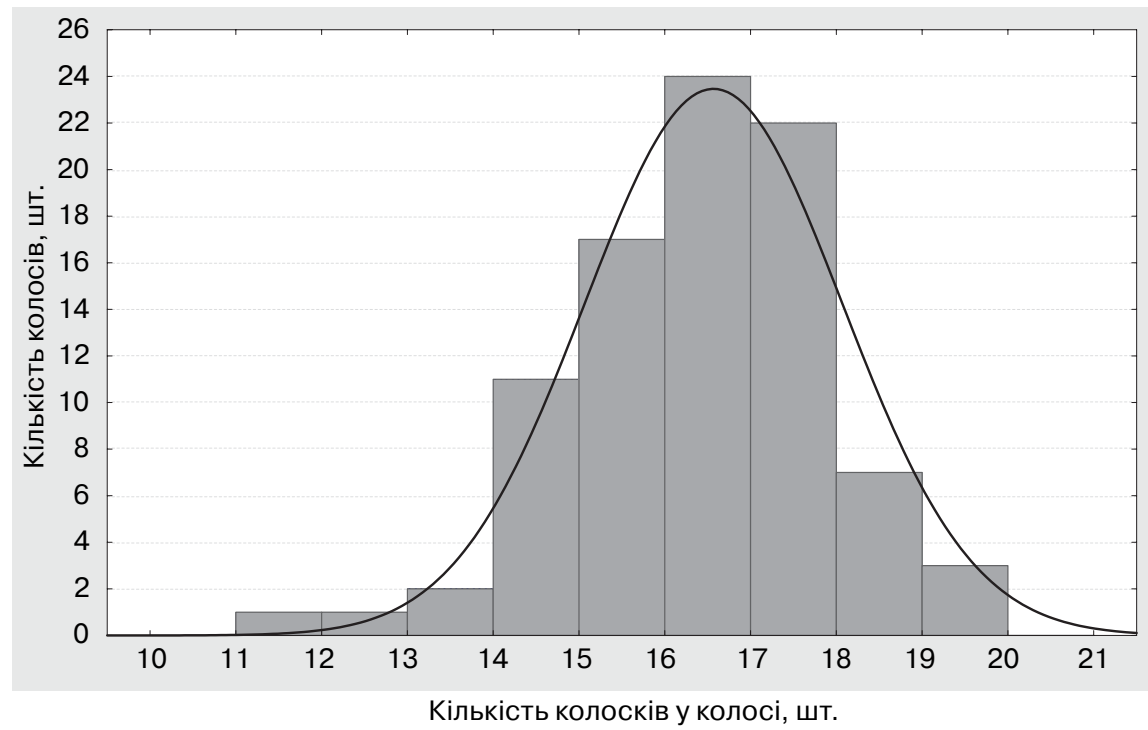

Рис. 1. Розподіл сортозразків пшениці озимої за ознакою «кількість колосків у колосі» (середнє за 2010-2012рр.)

У таблиці 1 надано характеристику колекційних зразків з найбільшою та найменшою кількістю колосків у колосі. Найбільшим цей показник був в українських сортозразків Вільшана (19,0 шт.), Декан (19,7 шт.), Знахідка / KS93 WERCZ (19,3 шт.), німецьких сортів SAMYRAJ (19,0 шт.), DROMOS (19,3 шт.), а також AC MACKINNON із CША (19,0 шт.), MILDA 3 Латвії (18,0 шт.), SEDA з Литви (18,0 шт.), NS-124-01 із Сербії (18,3 шт.) та 


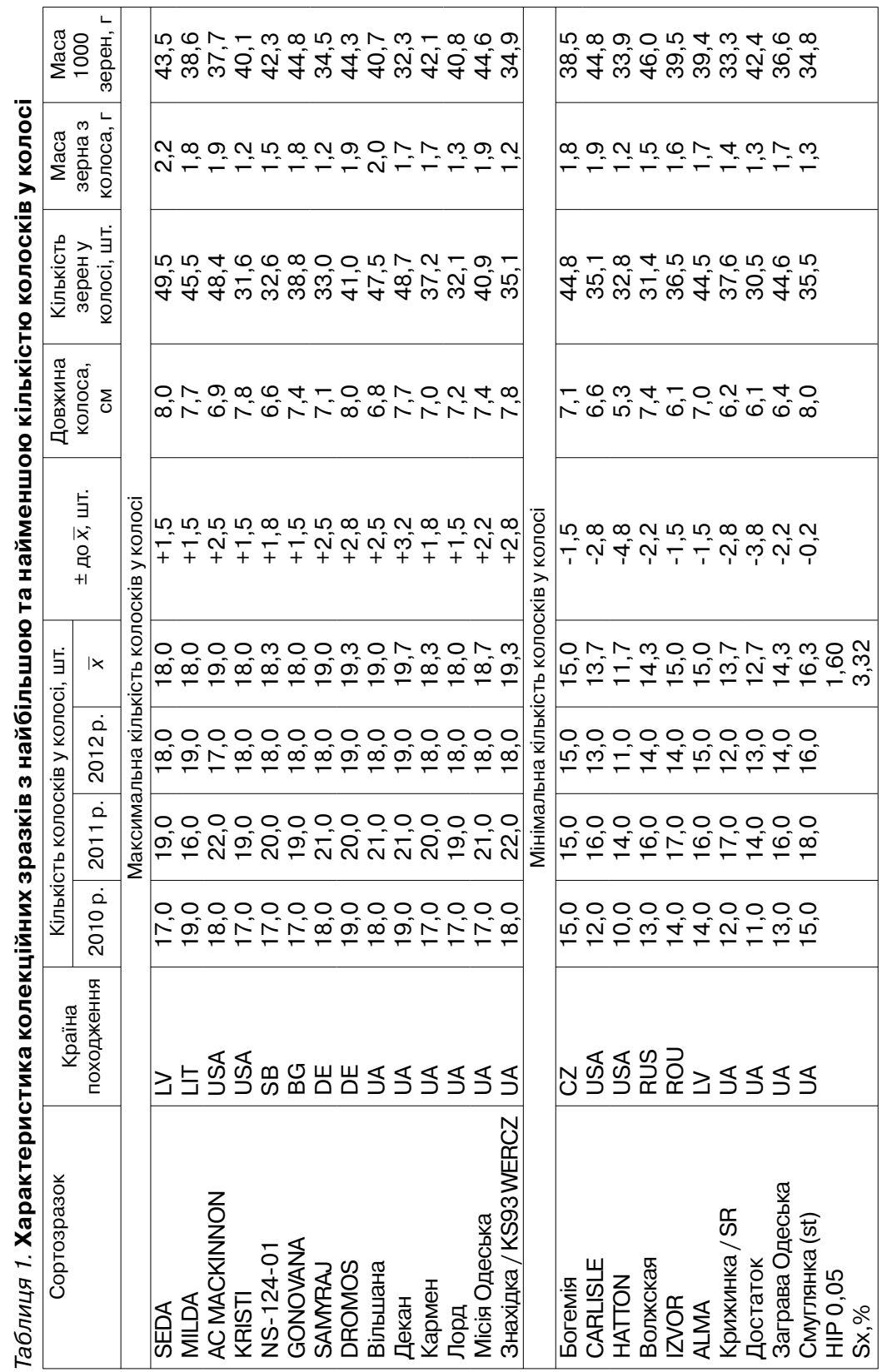


ін., найменшим - у сортів із США HATTON (11,7 шт.) та CARLISLE (13,7 шт.), українських Достаток (12,7 шт.), Солоха (14,3 шт.), Крижинка / SR (13,7 шт.), російського сорту Волжская (14,3 шт.) тощо.

Слід зазначити, що кількість колосків у колосі є досить мінливою за роками ознакою. Так, найбільші значення цього показника отримано у 2011 р., який характеризувався дещо вищою порівняно із середньобагаторічними даними температурою повітря та підвищеним вологозабезпеченням. Незначне підвищення температури на фоні дефіциту вологи у 2010 р. призвело до закладання мінімальної кількості колосків у колосі.

Довжина колоса також $\epsilon$ нестабільною за роками ознакою. За сприятливих умов 2011 р. цей показник був найбільшим, але дещо знизився за гірших умов 2010 та 2012 рр. (див. табл. 1).

У своїх дослідженнях ми не відмітили чіткого зв'язку кількості колосків у колосі з тривалістю вегетаційного періоду колекційних зразків. У таблиці 2 показано кореляційні зв'язки між елементами структури колоса.

Таблиця 2. Кореляційні зв'язки між елементами структури колоса досліджуваних колекційних зразків

\begin{tabular}{|l|c|c|c|c|c|}
\hline \multicolumn{1}{|c|}{ Показник } & $\begin{array}{c}\text { Кількість } \\
\text { колосків } \\
\text { у колосі, шт. }\end{array}$ & $\begin{array}{c}\text { Кількість } \\
\text { зерен } \\
\text { колосі, шт. }\end{array}$ & $\begin{array}{c}\text { Маса } \\
\text { зерна 3 } \\
\text { колоса, } г\end{array}$ & $\begin{array}{c}\text { Маса } \\
1000 \\
\text { зерен, } г\end{array}$ & $\begin{array}{c}\text { Довжина } \\
\text { колоса, } \\
\text { см }\end{array}$ \\
\hline Кількість зерен у колосі, шт. & 0,28 & & & & \\
Маса зерна з колоса, г & 0,21 & 0,78 & & & \\
Маса 1000 зерен, г & 0,04 & $-0,05$ & $\mathbf{0 , 5 4}$ & & \\
Довжина колоса, см & $\mathbf{0 , 5 7}$ & $\mathbf{0 , 2 6}$ & 0,17 & 0,02 & \\
Урожайність, г/м ${ }^{2}$ & 0,20 & $\mathbf{0 , 4 7}$ & $\mathbf{0 , 6 3}$ & $\mathbf{0 , 4 2}$ & 0,19 \\
\hline
\end{tabular}

Примітка. Напівжирним шрифтом виділено коефіцієнти кореляції, достовірні на рівні $p<0,05$

Найвищий кореляційний зв’язок кількості колосків у колосі з іншими ознаками встановлено для довжини колоса $(\mathrm{r}=+0,57)$. На позитивний зв'язок вказує й нахил лінії регресії (рис. 2).

Такий зв'язок $є$ значним або помірним відповідно до шкали Чеддока (цит. за [11]), де $\mathrm{r}=0,1-0,3$ - зв’язок слабкий, 0,3-0,5 - помірний, 0,5-0,7 - значний, 0,7-0,9 - сильний, 0,90-0,99 - дуже сильний, 1,0 - функціональний. Достовірними також були слабкі кореляційні зв'язки кількості колосків з кількістю зерен у колосі $(\mathrm{r}=+0,28)$ та масою зерна з колоса $(\mathrm{r}=$ $+0,21)$. Сильний зв’язок $(\mathrm{r}=+0,78)$ відмічено тільки між кількістю зерен у колосі та масою зерна з колоса.

Урожайність зразків мала помірний кореляційний зв’язок із кількістю зерен у колосі та масою 1000 зерен, значний - із масою зерна з колоса $(\mathrm{r}=+0,63)$. 3 кількістю колосків у колосі врожайність мала слабкий недостовірний зв'язок $(\mathrm{r}=+0,2, \mathrm{p}>0,05)$. 


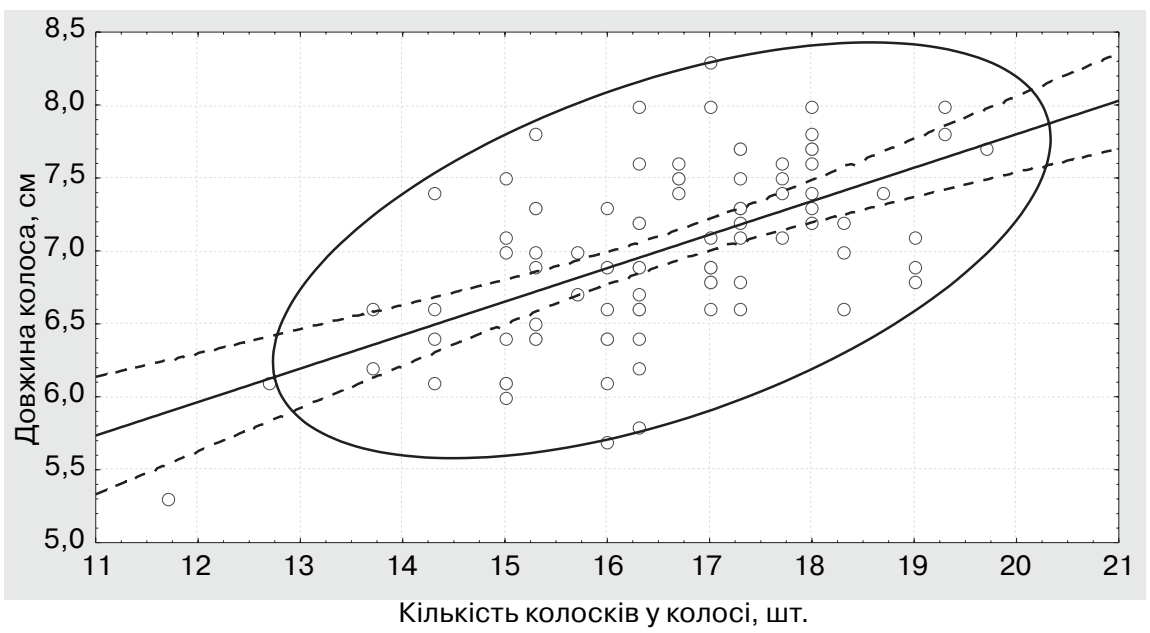

Рис. 2. Взаємозв'язок між кількістю колосків у колосі та довжиною колоса у сортозразків озимої пшениці

Висновки. У середньому за три роки (2010-2012) кількість колосків у колосі досліджуваних сортозразків озимої пшениці різного еколого-географічного походження коливалась від 11,7 до 19,7 шт. (середнє значення ознаки - 16,5 шт.), найбільшим цей показник був в українських сортозразків Вільшана (19,0 шт.), Декан (19,7 шт.), Знахідка / KS93 WERCZ (19,3 шт.), німецьких SAMYRAJ (19,0 шт.), DROMOS (19,3 шт.), а також AC MACKINNON із США (19,0 шт.), MILDA з Латвії (18,0 шт.), SEDA з Литви (18,0 шт.), NS-12401 із Сербії (18,3 шт.), найменшим - у сортів із США HATTON (11,7 шт.) та CARLISLE (13,7 шт.), українських Достаток (12,7 шт.), Солоха (14,3 шт.), Крижинка / SR (13,7 шт.) та російського сорту Волжская (14,3 шт.).

Встановлено значний кореляційний зв'язок кількості колосків у колосі з довжиною колоса $(\mathrm{r}=+0,57)$ та слабкий достовірний -3 кількістю зерен у колосі та масою зерна з колоса.

\section{Список використаних джерел}

1. Malcomber S. T., Preston J. C., Reinheimer R., Kossuth J., Kellogg E. A. Developmental gene evolution and the origin of grass inflorescence diversity. Advances in Botany Research. 2006. Vol. 44. P. 423-479. doi: 10.1016/S0065-2296(06)44011-8 2006

2. Pennell A. L., Halloran G. M. Inheritance of supernumerary spikelets in wheat. Euphytica. 1983. Vol. 32. P. 767-776.

3. Ahrens J. F., Loomis W. E. Floral induction and development in winter wheat. Crop Science. 1963. No. 3. P. 463-466.

4. Панченко Т. В., Лозінський М. В., Коваленко Р. В. Оцінка сортів озимої пшениці за густотою рослин та густотою продуктивного стеблостою в умовах дослідного поля ННДЦ БНАУ. Агробіологія : зб. наук. праць. Біла Церква : [б. в.], 2012. Вип. 7. C. $106-110$. 
5. Шелепов В. В., Гаврилюк М. М., Чебаков М. П., Гончар О. М., Вергунов В. А. Селекція, насінництво та сортознавство пшениці. Миронівка : [б. в.], 2007. 405 с.

6. Ходаніцький В., Ходаніцька О. Формування продуктивності колоса в зернових. Пропозиція. 2017. № 4. С. 78-80.

7. Бабаянц Л., Мештерхази А., Вехтер Ф. и др. Методы селекции и оценки устойчивости пшеницы и ячменя к болезням в странах-членах СЭВ. Прага : [б. и.], 1988. $312 \mathrm{c}$.

8. Методика державного сортовипробування сільськогосподарських культур / під ред. В. В. Волкодава. Київ : [б. в.], 2000. Вип. 1. 100 с.

9. Доспехов Б. А. Методика полевого опыта (с основами статистической обработки результатов исследований). 5-е изд., доп. и перераб. Москва : Агропромиздат, 1985. $351 \mathrm{c}$.

10. Афифи А., Эйзен С. Статистический анализ. Подход с использованием ЭВМ / пер. с англ. И. С. Енюкова, И. Д. Новикова; под ред. Г. П. Башарина. Москва : Мир, 1982. $488 \mathrm{c}$.

11. Плюта В. Сравнительный многомерный анализ в экономических исследованиях. Москва : Статистика, 1980. 150 с.

\section{References}

1. Malcomber, S. T., Preston, J. C., Reinheimer, R., Kossuth, J., \& Kellogg, E. A. (2006). Developmental gene evolution and the origin of grass inflorescence diversity. Adv. Bot. Res., 44, 423-479. doi 10.1016/S0065-2296(06)44011-8 2006

2. Pennell, A. L., \& Halloran, G. M. (1983). Inheritance of supernumerary spikelets in wheat. Euphytica, 32, 767-776.

3. Ahren, J. F., \& Loomis, W. E. (1963). Floral induction and development in winter wheat. Crop Sci. , 3, 463-466.

4. Panchenko, T. V., Lozinskyi, M. V., \& Kovalenko, R. V. (2012). Evaluation of winter wheat varieties by density of plants and density of productive stems in conditions of experimental field of ESEC BNAU. Agrobiology, 7, 106-110. [in Ukrainian]

5. Shelepov, V. V., Havryliuk, M. M., Chebakov, M. P., Honchar, O. M., \& Verhunov, V. A. (2007). Wheat Breeding, Seed Production, and Variety Science. Myronivka: N.p. [in Ukrainian]

6. Khodanitskyi, V., \& Khodanitska, O. (2017). Forming spike productivity in cereals. Proposition, 4, 78-80. [in Ukrainian]

7. Babayants, L., Mesterhazy, A., Wachter, F., Neklesa, N., Dubinina, L., Omel'chenko, L., Klechkovskaya, Ye., Slyusarenko, A., \& Bartosh, P. (1988). Methods of Breeding and Evaluating Wheat and Barley for Disease Resistance in Countries Being COMECON Members. Prague: N.p. [in Russian]

8. Volkodav, V. V. (Ed.). (2000). Methods of the State Strain Testing Crops. General Part. Kyiv: N.p. [in Ukrainian]

9. Dospekhov, B. A. (1985). Methods of Field Experiment (with the Basics of Statistical Processing of Research Results). (5 $5^{\text {th }}$ ed., rev.). Moscow: Agropromizdat. [in Russian]

10. Afifi, A. A., \& Azen, S. P. (1982). Statistical Analysis. A Computer Oriented Approach (I. S. Yenyukov, \& I. D. Novikov, Trans.). G. P. Basharin (Ed.). Moscow: Mir. [in Russian]

11. Plyuta, V. (1980). Comparative Multidimensional Analysis in Economic Research. Moscow: Statistika. [in Russian] 


\title{
Дифференциация коллекционных образцов пшеницы мягкой озимой по количеству колосков в колосе
}

\author{
Лытус Н. В. ${ }^{1}$ \\ Стариченко В. Н. ${ }^{2}$, кандидат сельскохозяйственных наук
}

1 Черкасская государственная сельскохозяйственная опытная станция
ННЦ «Институт земледелия НААН»

Украина, 20731, с. Холоднянское, ул. Докучаева, 13, Смелянский район Черкасской обл. e-mail: iznaan@ukr.net

${ }^{2}$ ННЦ «Институт земледелия НАAН»

Украина, 08162, пгт Чабаны, ул. Машиностроителей, 2-Б, Киево-Святошинский район Киевской обл.

e-mail: stvas@ukr.net

Цель. Проанализировать по количеству колосков в колосе коллекционный материал пшеницы мягкой озимой для получения селекционным путём генотипов с наследственно обусловленным большим числом колосков и высокой адаптивностью к абиотическим факторам. Методы. Исследования проводили в 2010-2012 гг. в полевых условиях селекционного севооборота Черкасской государственной сельскохозяйственной станции. Изучение и оценку коллекционного материала (87 сортообразцов пшеницы озимой разного эколого-географического происхождения) проводили по методикам ВИР и государственного сортоиспытания сельскохозяйственных культур, математическую обработку данных - методом дисперсионного анализа по Б. А. Доспехову и А. Афифи, С. Эйзену с использованием программ Microsoft Excel и Statistica 6.0. Изменчивость хозяйственно ценных признаков коллекционных образцов озимой пшеницы изучали по элементам продуктивности колоса (количество колосков в колосе, длина колоса, количество зерен в колосе, масса зерна с колоса, масса 1000 зерен) и урожайности. Результаты. Структурный анализ показал, что в среднем за три года исследований (2010-2012) количество колосков в колосе исследуемых сортообразцов озимой пшеницы разного эколого-географического происхождения колебалось от 11,7 до 19,7 шт. (среднее значение признака - 16,5 шт.), наибольшим этот показатель был у украинских сортообразцов Вільшана (19,0 шт.), Декан (19,7 шт.), Знахідка / KS93 WERCZ (19,3 шт.), немецких SAMYRAJ (19,0 шт.), DROMOS (19,3 шт.), а также AC MACKINNON из США (19,0 шт.), MILDA из Латвии (18,0 шт.), SEDA из Литвы (18,0 шт.), NS-124-01 из Сербии (18,3 шт.), наименьшим - у сортов из США HATTON (11,7 шт.) и CARLISLE (13,7 шт.), украинских Достаток (12,7 шт.), Солоха (14,3 шт.), Крижинка / SR (13,7 шт.) и российского сорта Волжская (14,3 шт.). Количество колосков в колосе - довольно изменчивый по годам признак. Не отмечено его связи с длительностью вегетационного периода. Самая высокая корреляционная связь количества колосков в колосе с другими признаками установлена для длины колоса $(r=+0,57)$. Выводы. Сортообразцы дифференцированы по количеству колосков в колосе. Установлена значительная корреляционная связь количества колосков в колосе с длиной колоса и слабая достоверная - с количеством зерен в колосе и массой зерна с колоса.

Ключевые слова: пшеница озимая, селекция, количество колосков в колосе, продуктивность колоса, эколого-географическое происхождение, урожайность 


\title{
Differentiation of collection samples of bread winter wheat by number of spikelets per spike
}

\author{
Lytus M. V. ${ }^{1}$ \\ Starychenko V. M. ${ }^{2}$, Candidate of Agricultural Sciences
}

'Cherkasy State Agricultural Research Station of NSC "Institute of Agriculture of NAAS"

13, Dokuchaieva St., Kholodnianske village, Smila district, Cherkasy region, 20731, Ukraine e-mail: iznaan@ukr.net

${ }^{2}$ National Scientific Center "Institute of Agriculture of NAAS"

$2 b$, Mashynobudivnykiv St., Chabany urban village, Kyiv-Sviatoshyn district, Kyiv region, 08162, Ukraine

e-mail: stvas@ukr.net

Purpose. To analyze the available collection of bread winter wheat by number of spikelets per spike for obtaining genotypes with hereditary more spikelets and high adaptability to abiotic factors by breeding. Methods. The study was carried out during 2010-2012 in field conditions of breeding crop rotation at the Cherkasy State Agricultural Research Station. Variability of agronomic traits was analyzed by elements of spike performance and yielding capacity. Studying and evaluating winter wheat collection material ( 87 variety samples of various ecological and geographical origin) were conducted on the methods of N. I. Vavilov Institute of Plant Industry and State Crop Variety Testing, mathematical processing of data was carried out according to B. A. Dospekhov and A. Afifi \& S. Azen when using the programs Microsoft Excel and Statistica 6.0. Results. On average for three years, the number of spikelets per spike varied from 11.7 to 19.7 with mean value being 16.5 . The most spikelets per spike was obtained in the Ukrainian variety samples Vilshana (19.0), Dekan (19.7), Znakhidka / KS93 WERCZ (19.3), the Germany ones SAMYRAJ (19.0), DROMOS (19.3) as well as AC MACKINNON (USA) (19.0), MILDA (Latvia) (18.0), SEDA (Lithuania) (18.0), and NS-124-01 (Serbia) (18.3). The least number of spikelets was observed in the varieties from the USA HATTON - 11.7, CARLISLE - 13.7, the Ukrainian varieties Dostatok 12.7, Solokha - 14.3, Kryzhynka / SR - 13.7, as well as Volzhskaya (Russia) - 14.3. The number of spikelets per spike is varying enough trait over the years. No its correlation with duration of cropping season was found. There was observed the highest correlation between the number of spikelets per spike and the spike length $(r=+0.57)$. Conclusions. The varieties studied were differentiated by number of spikelets per spike. There were ascertained significant correlation between number of spikelets per spike and spike length, weak reliable correlation with grain number per spike and grain weight per spike.

Key words: winter wheat, breeding, number of spikelets per spike, spike performance, ecological and geographical origin, yielding capacity 